\title{
Effects of niacin supplementation (40 weeks) and two dietary levels of concentrate on performance, blood and fatty acid profiles of dairy cattle
}

\author{
C. Rauls ${ }^{1}$, U. Meyer ${ }^{1 \#}$, L. Hüther ${ }^{1}$, D. von Soosten ${ }^{1}$, A. Kinoshita ${ }^{2}$, J. Rehage $^{2}$, \\ G. Breves ${ }^{3} \&$ S. Dänicke ${ }^{1}$ \\ ${ }^{1}$ Institute of Animal Nutrition, Friedrich-Loeffler-Institut (FLI), Federal Research Institute for Animal Health, \\ Braunschweig, Germany; ${ }^{2}$ Clinic for Cattle, ${ }^{3}$ Department of Physiology. University of Veterinary Medicine Hanover, \\ Foundation, Hanover, Germany
}

(Received 30 July 2014; Accepted 28 May 2015; First published online 10 October 2015)

Copyright resides with the authors in terms of the Creative Commons Attribution 2.5 South African Licence.
See: http://creativecommons.org/licenses/by/2.5/za
Condition of use: The user may copy, distribute, transmit and adapt the work, but must recognise the authors and the South African
Journal of Animal Science.

\begin{abstract}
The present study was conducted to investigate the effects of $24 \mathrm{~g}$ niacin (nicotinic acid (NA)) supplementation over 40 weeks with two forage-to-concentrate ratios $(60 \%$ concentrate vs. $30 \%$ in the total diet) on performance variables of energy metabolism such as plasma concentrations of non-esterified fatty acids (NEFA), beta-hydroxybutyrate (BHB), glucose and nicotinamide (NAM), and the fatty acid profile in rumen fluid. In a $2 \times 2$ factorial design, 64 German Holstein cows were divided postpartum into four dietary groups: i) $60 \%$ concentrate supplemented with $24 \mathrm{~g} \mathrm{NA}$ (Group $60+\mathrm{NA}$ ); ii) $60 \%$ concentrate without NA (Group 60-); iii) 30\% concentrate with $24 \mathrm{~g}$ NA (Group $30+$ NA) and iv) 30\% concentrate without NA (Group 30-). The experiment started on the day of calving and continued for 40 weeks. Niacin supplementation did not affect milk yield or composition. The plasma niacin content increased in the supplemented groups, especially Group 30 + NA. Niacin supplementation led to decreased plasma glucose concentrations. The interaction of concentrate $x$ niacin enhanced the molar proportion of propionic acid in rumen fluid in Group 60 + NA. Total short-chain fatty acid (SCFA) concentrations were increased by level of concentrate, niacin supplementation and the interaction, concentrate $x$ niacin. Plasma levels of NEFA and BHB remained unaffected. In sum, concentrate level, niacin supplementation and the interaction of concentrate $x$ niacin increased plasma NAM concentration, whereas plasma glucose concentration was decreased by niacin supplementation.
\end{abstract}

Keywords: Milk performance, nicotinic acid, plasma metabolites, rumen fluid composition

${ }^{\#}$ Corresponding author: ulrich.meyer@fli.bund.de

\section{Introduction}

It is assumed that ruminants cover their niacin requirements through feed, endogenous synthesis from tryptophan and microbial synthesis by rumen microbes (German Society of Nutrition Physlology (GfE), 2001; NRC, 2001). Ruminal niacin synthesis occurs, as well as degradation. Several studies showed that ruminal synthesis might vary when different feeding regimens were applied. Feeding diets containing high levels of concentrate increased the ruminal niacin concentration (Hayes et al., 1966; Nilson et al., 1967; Girard, 1994). Santschi et al. (2005b) assumed that ruminal niacin supply depends on diet composition, and that there are indications that the metabolism of supplemental niacin is influenced. Although it was presumed that ruminal niacin synthesis is sufficient for dairy cows with average performance level (Girard, 1998; GfE, 2001), this is possibly not always the case (Flachowsky, 1993; Girard \& Matte, 2005; Breves \& Lebzien, 2009). Weiss \& Ferreira (2006) suggested that the requirements of dairy cattle tend to exceed the capacity of rumen microorganisms to synthesize sufficient amounts of vitamins of the $B$ complex, owing to the improvement in the genetic potential of cows for higher milk yield. Recent studies have revealed beneficial effects of niacin supplementation on performance (Cervantes et al., 1996; Drackley et al., 1998) and energy metabolism (Erickson et al., 1992; DiCostanzo et al., 1997). Drackley et al. (1992) reviewed 24 trials, which included 40 treatment comparisons with niacin supplementation, and, in most cases, found positive responses to supplemental niacin. Average responses to supplemented niacin resulted in increased milk production, but in most studies only early lactation was considered. Niacin supplementation decreased blood 
non-esterified fatty acid (NEFA) and beta-hydroxybutyrate (BHB) concentrations, while blood glucose concentration was increased in ketotic cows (Fronk et al., 1980). Pires \& Grummer (2007) found decreased plasma NEFA concentration and ketone bodies due to supplemental nicotinic acid in feed-restricted cows.

Previous findings revealed mainly positive effects of niacin supplementation, but results are contradictory. This may be because of conditions such as the type of niacin that is used (encapsulated or not) and its analysis, amount of niacin supplementation, age of cows, feeding regimen, time of sampling, different blood fractions and stage of lactation. In addition, there is a shortage of results from long-term experiments concerning high-dose niacin supplementation to primiparous and multiparous dairy cows.

Feeding a diet with a high level of concentrate is common practice, especially at peak lactation, and aims at compensating for the energy deficit that typically occurs after calving. Such diets are known to alter the ruminal microbial communities and fermentative pattern, and might therefore affect the ruminal synthesis of niacin. Therefore, the aim of the investigation was to measure the effects of two levels of concentrate in the diet, in the presence or absence of supplemental niacin, on milking performance and selected rumen fluid and blood parameters.

\section{Material and Methods}

The study was conducted at the experimental station of the Institute of Animal Nutrition, FriedrichLoeffler-Institute, Braunschweig, Germany, according to the German Animal Protection Act (Tierschutzgesetz) in the version officially published on 18 May 2006 and approved by the Lower Saxony State Office for Consumer Protection and Food Safety. Sixty-four German Holstein cows (38 multiparous, with lactation numbers ranging from second to fifth lactation and 26 primiparous) were assigned to one of four dietary treatments according to mean milk yield, number of lactation and bodyweight. The experimental diets contained high (60\%) or low (30\%) levels of concentrate, and were unsupplemented (60- vs. 30-) or supplemented with $24 \mathrm{~g}$ niacin/cow/day $(60+\mathrm{NA}$ vs. $30+\mathrm{NA})$ (Table 1$)$.

Table 1 Experimental design

\begin{tabular}{lccc}
\hline Group & Concentrate ratio $\mathbf{\%}^{\mathbf{1}}$ & Niacin (g/cow/d) & N \\
\hline $60+$ NA & 60 & 24 & 16 \\
$60-$ & 60 & 0 & 16 \\
$30+$ NA & 30 & 24 & 16 \\
$30-$ & 30 & 0 & 16 \\
\hline
\end{tabular}

${ }^{1} \%$ in total ration; NA: niacin: N: number of cows.

The niacin contained at least 99.5\% nicotinic acid (Lonza Ltd., Basel, Switzerland), and was powdered and pelleted with the concentrate allowance per treatment. The rations were formulated according to the recommendations of the GfE (2001). The cows had free access to water. The study was performed from the day of calving to the 40th week of lactation. The compositions of concentrate and roughage are given in Table 2.

The cows were housed in pens according to their feeding group, in a free-stall barn equipped with slatted floors and cubicles covered with rubber mattresses. The roughage was offered in self-feeding stations (Type MJ/ RIC, Insentec, B.V., Marknesse, The Netherlands), which were re-filled daily at approximately 10:00. Concentrate was provided via computerized feeding stations (Type MJ, Insentec, B.V., Marknesse, The Netherlands). All animals were equipped with ear transponders to record the daily animal individual feed intake. Feed was provided ad libitum, but to achieve the intended concentrate-to-roughage ratios in the various feeding groups, the amount of concentrate was adjusted twice weekly according to individual roughage intake. The experiment started individually for each cow on the day of calving. Representative concentrate samples were taken weekly, and maize and grass silage samples twice a week, and pooled over approximately four-week periods.

The cows were milked at 5:30 and 15:30, and individual milk yields were recorded daily by automatic milk counters (Lemmer Fullwood GmbH, Lohmar, Germany). Samples for analysis of milk composition were taken twice a week, conserved with bronopol, and stored at $8{ }^{\circ} \mathrm{C}$, prior to analysis. Bodyweight was recorded automatically when the animal left the milking parlour. 
Table 2 Composition, nutrient and energy content of concentrates and roughage

\begin{tabular}{|c|c|c|c|c|c|}
\hline & \multicolumn{4}{|c|}{ Concentrate $^{1}$} & \multirow[b]{2}{*}{ Roughage $^{2}$} \\
\hline & Con $60+N A$ & Con 60- & Con $30+N A$ & Con 30- & \\
\hline \multicolumn{6}{|l|}{ Components in \% } \\
\hline Soybean meal & 26.8 & 26.8 & 26 & 26 & \\
\hline Wheat grain & 50 & 50 & 50 & 50 & \\
\hline Maize grain & 20.8 & 20.8 & 20 & 20 & \\
\hline Mineral premix ${ }^{3}$ & 2.4 & 2.4 & 4 & 4 & \\
\hline Niacin (g/kg DM) & 1.76 & - & 3.52 & - & \\
\hline \multicolumn{6}{|l|}{ Crude nutrients (g/kg DM) } \\
\hline Crude ash & 49 & 51 & 62 & 63 & 58 \\
\hline Crude protein & 224 & 219 & 219 & 217 & 106 \\
\hline Ether extract & 30 & 30 & 30 & 30 & 34 \\
\hline Crude fibre & 34 & 34 & 34 & 33 & 220 \\
\hline Neutral detergent fibre & 156 & 185 & 130 & 128 & 440 \\
\hline Acid detergent fibre & 47 & 47 & 47 & 47 & 241 \\
\hline Net energy ${ }^{4}\left(\mathrm{MJ} \mathrm{NE}_{\llcorner} / \mathrm{kg}\right)$ & 8.3 & 8.3 & 8.2 & 8.2 & 6.4 \\
\hline \multicolumn{6}{|c|}{ 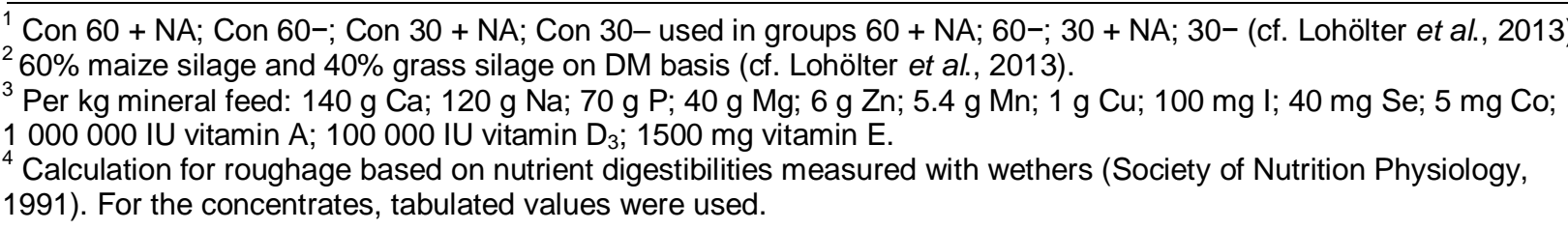 } \\
\hline
\end{tabular}

Rumen fluid and blood samples were taken from nine cows from each feeding group (five primiparous and four multiparous cows). Samples were collected three weeks ante partum and 1, 3, 16 and 36 weeks postpartum. Rumen fluid samples were taken via oral rumen tubes. Approximately $100 \mathrm{~mL}$ of rumen fluid was collected from the ventral sac through the oral rumen tube with a hand vacuum pump. Fluid was collected at 8:00 after feed withdrawal of at least $2.5 \mathrm{~h}$. After measuring the $\mathrm{pH}$ value, samples were centrifuged at $1680 \times g$ for 5 minutes at $4{ }^{\circ} \mathrm{C}$. Then $1 \mathrm{~mL}$ sulphuric acid (25\%) was added to $10 \mathrm{~mL}$ supernatant and samples were centrifuged again. The supernatant was kept frozen at $-20{ }^{\circ} \mathrm{C}$ for later measurement of the profile and concentration of volatile fatty acids.

Blood was collected from the vena jugularis externa into heparin tubes (clinical chemistry) and monovettes (niacin analysis). Approximately one hour after sampling, plasma and serum were separated by centrifugation at $3000 \times g$ for 30 minutes at $15^{\circ} \mathrm{C}$. Serum for niacin analysis was stored at $-80{ }^{\circ} \mathrm{C}$, and plasma for analysis of other blood parameters was kept at $-18^{\circ} \mathrm{C}$.

The composition of the feedstuffs was determined according to the methods of the Association of German Agricultural Analysis and Research Centres (VDLUFA, 2007). Crude ash (ash) was analysed by method 8.1, and crude fibre (CF) and ether extract (EE) were determined by methods 6.1.1 and 5.1.1, respectively. Crude protein (CP) was analysed using the Dumas combustion method (method 4.1.2). Neutral detergent fibre (NDF) was determined as described by Van Soest et al. (1991) and acid detergent fibre (ADF) analysis according to method 6.5.2 of VDLUFA (2007). Both levels were expressed without residual ash. The niacin concentration in feedstuff was determined microbiologically using Lactobacillus plantarum as an indicator strain (VDLUFA method). Milk samples were analysed for fat, protein and lactose concentrations, using an infrared milk analyser (Milkoscan FT 6000, combined with a Fossomatic 5000, Foss Electric, Hillerød, Denmark).

The $\mathrm{pH}$ of rumen fluid was measured immediately after collection (pH525, WTW, Weilheim, Germany). SCFA were analysed with a gas chromatograph (Hewlett Packard 5580, Avondale, Phil., USA), equipped with a flame ionization detector as described by Geissler et al. (1976). Plasma was analysed for glucose, NEFA and BHB concentrations, and glucose analysis was performed with the hexokinase assay (ABX, Art. A11A22116). NEFA concentrations were determined via an enzymatic colour test (Art. 99475409, Wako Chemicals GmbH, Neuss, Germany). An enzymatic UV test was applied to measure concentrations of BHB 
(Art. RB 1008, Randox Laboratories $\mathrm{GmbH}$, Krefeld). Niacin concentration in plasma was determined with high performance liquid chromatography (HPLC), as described by Niehoff et al. (2009b).

The net energy requirements for maintenance $\left(\mathrm{NE}_{\mathrm{M}}\right)$ and lactation $\left(N E_{\mathrm{L}}\right)$, based on equations published by the Society of Nutrition Physiology (GfE, 2001), were calculated as follows:

$\mathrm{NE}_{\mathrm{M}}(\mathrm{MJ} \mathrm{NE} / \mathrm{d})=0.293 \times \mathrm{BW}^{0.75}$

Milk energy concentration $\left(\mathrm{MJ} \mathrm{NE}_{\mathrm{L}} / \mathrm{kg}\right)=0.38 \times$ milk fat $(\%)+0.21 \times$ milk protein $(\%)+0.95$

$\mathrm{NE}_{\mathrm{L}}\left(\mathrm{MJ} \mathrm{NE} \mathrm{L}_{\mathrm{L}} / \mathrm{d}\right)=\left[\right.$ milk energy concentration $\left.\left(\mathrm{MJ} \mathrm{NE}_{\mathrm{L}} / \mathrm{kg}\right)+0.086\right] \times$ milk yield $(\mathrm{kg} / \mathrm{d})$

4\% fat-corrected milk (FCM) was estimated as:

$\mathrm{FCM}[\mathrm{kg} / \mathrm{d}]=(($ milk fat $[\%] \times 0.15)+0.4) \times$ milk yield $[\mathrm{kg} / \mathrm{d}]($ Gaines, 1928, page 405$)$

The energy balance was calculated as follows: $\left(M J N E_{L} / d\right)-\left[N E_{M}\left(M J N E_{L} / d\right)+N E_{L}\left(M J N E_{L} / d\right)\right]$

Energy intake was calculated by multiplying the daily dry matter intake (DMI) with the energy concentration of the whole ration. Daily feed intake, live weight and milk constituents were pooled to obtain weekly means before data analysis.

Statistical analysis of performance parameters was generally based on the individual weekly mean. Statistical analysis was carried out using the software package SAS version 9.1 (SAS, 2008). All parameters were analysed as repeated measures, using the MIXED procedure. In the model, dietary concentrate proportion, niacin supplementation, parity, week of lactation and their interactions were regarded as fixed effects, while the individual cow was handled as a random variable. For all analyses, significance was declared when $P$-values were $<0.05$, and a tendency was noted when $0.05<P<0.10$.

\section{Results}

From the initial pool of 64 cows, 60 completed the whole experimental period of 40 weeks. In the beginning, two cows were replaced after dystocia (Groups 60- and $30+\mathrm{NA}$ ). During the trial, the replacement cow in Group 60- was exchanged again because of dystocia. The replacement cow in Group $30+$ NA finished the 16th week of lactation, and was then removed owing to sickness (lameness, week 31.) Consequently, the data were lost from one animal in the third week ante partum (Group 60-) and one in the 36th week of lactation (Group $30+\mathrm{NA})$.

Table 3 shows the effects of concentrate level and niacin supplementation on DMI and milk production. Table 4 depicts the fatty acid profile of rumen fluid and blood parameters. The intake of concentrate and roughage largely met the intended proportions in the various feeding groups. The animals received the expected concentrate and roughage ratio: Group $60+$ NA: $59 \pm 3 \%$ vs. $41 \pm 8 \%$; Group 60-: 56 $\pm 7 \%$ vs. $44 \pm 7 \%$; Group $30+$ NA: $29 \pm 7 \%$ vs. $71 \pm 5 \%$; Group $30-: 30 \pm 2 \%$ vs. $70 \pm 5 \%$. The daily NA supplementation of $24 \mathrm{~g} / \mathrm{cow}$ was slightly lower than intended: Group $60+$ NA obtained $21.0 \pm 0.3 \mathrm{~g}$ total niacin/cow/day, while Group $30+$ NA received $20.5 \pm 0.2 \mathrm{~g}$. The niacin intake of Group 60- amounted to 2.8 $\pm 0.03 \mathrm{~g}$, and Group 30- consumed $1.0 \pm 0.0 \mathrm{~g}$ daily.

Changes in DMI for pluriparous cows and primiparous cows over the 40 weeks are shown in Figure 1. In early lactation (until week 8 ) the groups fed $60 \%$ concentrate had a higher increase of DMI, and Group 60 + NA had a steeper increase compared with Group 60-, resulting in DMI that was $0.85 \mathrm{~kg} / \mathrm{d}$ higher (weeks 4 - 8) than in Group 60-. However, in almost the entire lactation period - and present mainly in the multiparous cows - Group 60 + NA showed a higher DMI than Group 60-. This did not occur in the combination of low concentrate with supplemental niacin, where the result was reversed. The cows from Group $30+$ NA showed lower DMI than Group 30- from the fifth week of lactation, while most of the time the primiparous cows of Group 30 + NA exhibited a higher DMI (Figure 1).

Concentrate level influenced almost all of the parameters, except milk fat yield and milk lactose percentage. Feeding high levels of concentrate increased milk yield $(P=0.001)$ and FCM yield $(P=0.011)$, but these parameters were not affected by niacin supplementation. In terms of the primiparous cows receiving niacin, there was increased milk yield, especially in early lactation compared with the unsupplemented primiparous cows. 


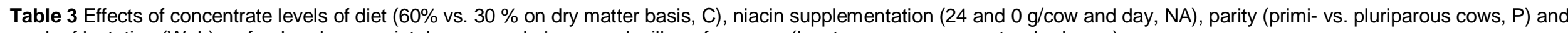
week of lactation (WoL) on feed and energy intake, energy balance and milk performance (least square means \pm standard error)

\begin{tabular}{|c|c|c|c|c|c|c|c|c|c|c|c|c|c|}
\hline \multirow[b]{2}{*}{ Intake } & \multicolumn{4}{|c|}{ Treatment group } & \multicolumn{9}{|c|}{$P$-value } \\
\hline & $\begin{array}{l}60+N A \\
(n=16)\end{array}$ & $\begin{array}{c}60- \\
(n=16)\end{array}$ & $\begin{array}{l}30+N A \\
(n=16)\end{array}$ & $\begin{array}{c}30- \\
(n=16)\end{array}$ & C & NA & CxNA & $\mathbf{P}$ & WoL & CxP & NAxP & CxNAxP & CxNAxPxWoL \\
\hline DMI (kg/d) & $19.1 \pm 0.2$ & $18.4 \pm 0.2$ & $18.8 \pm 0.3$ & $19.5 \pm 0.2$ & 1.137 & 0.902 & 0.003 & $<0.001$ & $<0.001$ & 0.035 & 0.088 & 0.011 & $<0.001$ \\
\hline Crude protein intake $(\mathrm{kg} / \mathrm{d})$ & $3.5 \pm 0$ & $3.3 \pm 0$ & $2.7 \pm 0$ & $2.8 \pm 0$ & $<0.001$ & 0.182 & 0.000 & $<0.001$ & $<0.001$ & 0.233 & 0.296 & 0.005 & $<0.001$ \\
\hline Energy intake (MJ $\left.\mathrm{NE}_{\mathrm{L}} / \mathrm{d}\right)$ & $144.7 \pm 1.8$ & $138.1 \pm 1.7$ & $130.7 \pm 1.9$ & $135.8 \pm 1.7$ & $<0.001$ & 0.663 & 0.001 & $<0.001$ & $<0.001$ & 0.167 & 0.106 & 0.005 & $<0.001$ \\
\hline Energy balance $\left(\mathrm{MJ} \mathrm{NE}_{\mathrm{L}} / \mathrm{d}\right)$ & $15.7 \pm 2.1$ & $11.8 \pm 2.0$ & $14.7 \pm 2.2$ & $18.9 \pm 2.0$ & 0.148 & 0.943 & 0.054 & $<0.001$ & 0.000 & 0.002 & 0.111 & 0.072 & 0.000 \\
\hline Milk & $(n=16)$ & $(n=16)$ & $(n=16)$ & $(n=16)$ & & & & & & & & & \\
\hline Yield $(\mathrm{kg} / \mathrm{d})$ & $31.1 \pm 1.1$ & $28.5 \pm 1.1$ & $26.1 \pm 1.2$ & $25.7 \pm 1.1$ & 0.001 & 0.187 & 0.357 & $<0.001$ & $<0.001$ & 0.457 & 0.042 & 0.624 & $<0.001$ \\
\hline Fat (\%) & $3.77 \pm 0.08$ & $4.03 \pm 0.08$ & $4.59 \pm 0.08$ & $4.55 \pm 0.08$ & $<0.001$ & 0.181 & 0.060 & 0.737 & $<0.001$ & 0.744 & 0.454 & 0.529 & 0.115 \\
\hline Fat $(\mathrm{kg} / \mathrm{d})$ & $1.15 \pm 0.03$ & $1.20 \pm 0.03$ & $1.19 \pm 0.03$ & $1.16 \pm 0.03$ & 0.987 & 0.816 & 0.151 & $<0.001$ & 0.000 & 0.528 & 0.000 & 0.623 & 0.012 \\
\hline Protein (\%) & $3.49 \pm 0.03$ & $3.50 \pm 0.03$ & $3.36 \pm 0.04$ & $3.40 \pm 0.03$ & 0.001 & 0.418 & 0.751 & 0.119 & $<0.001$ & 0.038 & 0.588 & 0.659 & 0.338 \\
\hline Protein $(\mathrm{kg} / \mathrm{d})$ & $1.08 \pm 0.03$ & $1.04 \pm 0.03$ & $0.87 \pm 0.03$ & $0.86 \pm 0.03$ & $<0.001$ & 0.418 & 0.671 & $<0.001$ & $<0.001$ & 0.829 & 0.029 & 0.811 & 0.001 \\
\hline Lactose (\%) & $4.80 \pm 0.01$ & $4.81 \pm 0.01$ & $4.80 \pm .0 .02$ & $4.77 \pm 0.01$ & 0.061 & 0.424 & 0.164 & $<0.001$ & $<0.001$ & 0.589 & 0.204 & 0.214 & 0.019 \\
\hline Lactose $\mathrm{kg} / \mathrm{d}$ & $1.50 \pm 0.05$ & $1.45 \pm 0.05$ & $1.26 \pm 0.06$ & $1.22 \pm 0.05$ & $<0.001$ & 0.392 & 0.888 & $<0.001$ & $<0.001$ & 0.750 & 0.077 & 0.850 & $<0.001$ \\
\hline FCM $(\mathrm{kg} / \mathrm{d}) \mathrm{x}$ & $30.0 \pm 0.7$ & $30.0 \pm 0.7$ & $28.6 \pm 0.7$ & $27.8 \pm 0.7$ & 0.011 & 0.572 & 0.549 & $<0.001$ & $<0.001$ & 0.716 & 0.001 & 0.932 & 0.016 \\
\hline F-P-Q & $1.08 \pm 0.02$ & $1.15 \pm 0.02$ & $1.37 \pm 0.02$ & $1.34 \pm 0.02$ & $<0.001$ & 0.164 & 0.002 & 0.466 & $<0.001$ & 0.179 & 0.127 & 0.124 & 0.006 \\
\hline
\end{tabular}

DMI: dry matter intake; $\mathrm{NE}_{\mathrm{L}}$ : net energy for lactation; FCM: fat corrected milk; F-P-Q: fat-protein-quotient. 
Table 4 Effects of concentrate levels of diet (30\% vs. $60 \%$ on dry matter basis, C), niacin supplementation ( 24 and 0 g/cow and day, NA), parity (primi- vs. pluriparous cows, $\mathrm{P}$ ) and week of lactation (WoL) on rumen fluid composition and blood parameters (LS MEANS \pm standard error)

\begin{tabular}{|c|c|c|c|c|c|c|c|c|c|c|c|c|c|}
\hline & \multicolumn{4}{|c|}{ Treatment group } & \multicolumn{9}{|c|}{$P$-value } \\
\hline & $60+N A$ & $60-$ & $30+N A$ & $30-$ & C & NA & CxNA & $\mathbf{P}$ & WoL & CxP & NAxP & CxNAxP & CxNAxPxWoL \\
\hline Rumen fluid & $(n=9)$ & $(n=9)$ & $(n=9)$ & $(n=9)$ & & & & & & & & & \\
\hline $\mathrm{pH}$ & $6.85 \pm 0.04$ & $6.93 \pm 0.04$ & $6.96 \pm 0.04$ & $6.88 \pm 0.04$ & 0.470 & 0.998 & 0.055 & 0.850 & 0.001 & 0.525 & 0.572 & 0.518 & 0.124 \\
\hline $\begin{array}{l}\text { Propionic acid (mol/100 } \\
\mathrm{mol})\end{array}$ & $\begin{array}{c}29.32 \pm \\
0.82\end{array}$ & $\begin{array}{c}26.24 \pm \\
0.83\end{array}$ & $\begin{array}{c}20.35 \pm \\
0.86\end{array}$ & $\begin{array}{c}20.96 \pm \\
0.82\end{array}$ & $<0.001$ & 0.144 & 0.031 & 0.086 & 0.041 & 0.386 & 0.099 & 0.865 & 0.008 \\
\hline Acetic acid (mol/100 mol) & $\begin{array}{c}55.11 \pm \\
0.88\end{array}$ & $\begin{array}{c}55.61 \pm \\
0.89\end{array}$ & $\begin{array}{c}62.78 \pm \\
0.91\end{array}$ & $\begin{array}{c}61.25 \pm \\
0.88\end{array}$ & $<0.001$ & 0.568 & 0.263 & 0.445 & 0.155 & 0.698 & 0.280 & 0.444 & 0.006 \\
\hline Valeric acid (mol/100 mol) & $2.70 \pm 0.22$ & $2.68 \pm 0.22$ & $1.41 \pm 0.23$ & $1.57 \pm 0.22$ & $<0.001$ & 0.738 & 0.698 & 0.505 & 0.200 & 0.644 & 0.800 & 0.359 & 0.098 \\
\hline SCFA total (mmol/L) & $138.1 \pm 4.7$ & $\begin{array}{c}107.09 \pm \\
4.7\end{array}$ & $111.9 \pm 4.9$ & $107.7 \pm 4.7$ & 0.001 & $<0.001$ & 0.050 & 0.756 & 0.002 & 0.087 & 0.042 & 0.032 & 0.277 \\
\hline Plasma metabolites & $(n=9)$ & $(n=9)$ & $(n=9)$ & $(n=9)$ & & & & & & & & & \\
\hline Glucose (mmol/L) & $3.62 \pm 0.07$ & $3.66 \pm 0.07$ & $3.59 \pm 0.07$ & $3.89 \pm 0.07$ & 0.128 & 0.014 & 0.062 & $<0.001$ & 0.068 & 0.226 & 0.462 & 0.567 & 0.001 \\
\hline $\mathrm{BHB}(\mathrm{mmol} / \mathrm{L})$ & $0.42 \pm 0.03$ & $0.47 \pm 0.03$ & $0.70 \pm 0.04$ & $0.66 \pm 0.03$ & $<0.001$ & 0.799 & 0.253 & 0.222 & 0.009 & 0.851 & 0.368 & 0.177 & 0.013 \\
\hline NEFA $(\mu \mathrm{mol} / \mathrm{L})$ & $305 \pm 37$ & $420 \pm 37$ & $364 \pm 38$ & $355 \pm 37$ & 0.923 & 0.168 & 0.105 & 0.676 & 0.001 & 0.952 & 0.830 & 0.828 & 0.108 \\
\hline Nicotinamide $(\mu \mathrm{g} / \mathrm{mL})^{\perp}$ & $0.77 \pm 0.03$ & $0.51 \pm 0.03$ & $1.28 \pm 0.03$ & $0.43 \pm 0.03$ & $<0.001$ & $<0.001$ & $<0.001$ & 0.977 & $<0.001$ & 0.008 & 0.766 & 0.011 & $<0.001$ \\
\hline
\end{tabular}

SCFA: short chain fatty acids; BHB: beta-hydroxybutyrate; NEFA: non-esterified fatty acid.

${ }^{1}$ Nicotinic acid concentration was below limit of determination. 

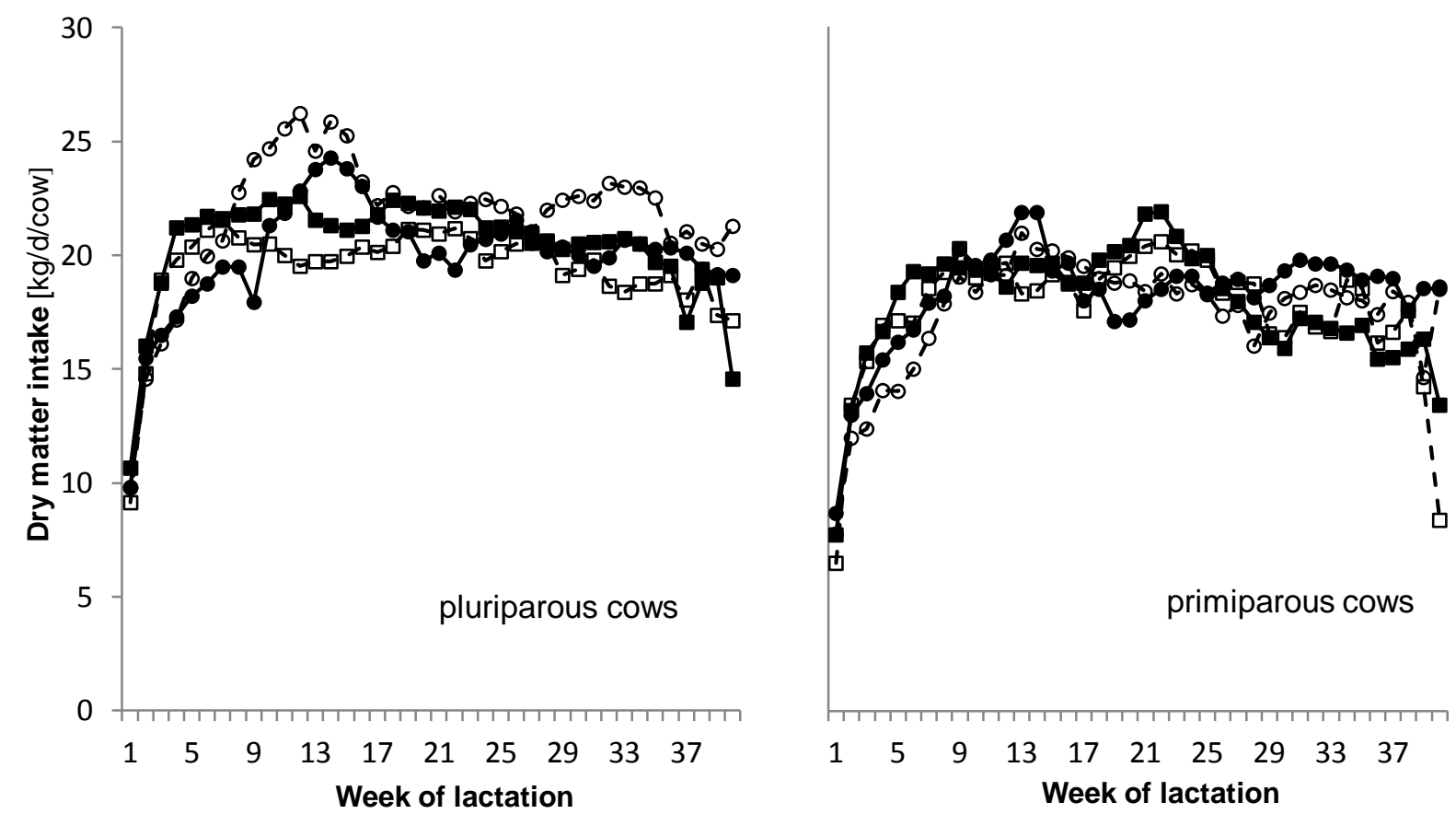

Figure 1 Changes in dry matter intake (means) over the experimental period of 40 weeks:

$\longrightarrow 60+N A ;--7-60-;$

Because such effects were not observed in pluriparous cows, interactions between niacin and parity for milk $(P=0.042)$ and FCM yield $(P=0.001)$ might be explained. The milk and FCM yield were increased over the entire lactation period, resulting in $6.0 \mathrm{~kg} / \mathrm{d}$ more yield and $2.3 \mathrm{~kg} / \mathrm{d} \mathrm{more}$ FCM, respectively, in primiparous cows in the $60 \%$ concentrate groups and $2.4 \mathrm{~kg} / \mathrm{d}$ yield and $3.2 \mathrm{~kg} / \mathrm{d}$ FCM, respectively, in the groups receiving 30\% concentrate (Figure 2).
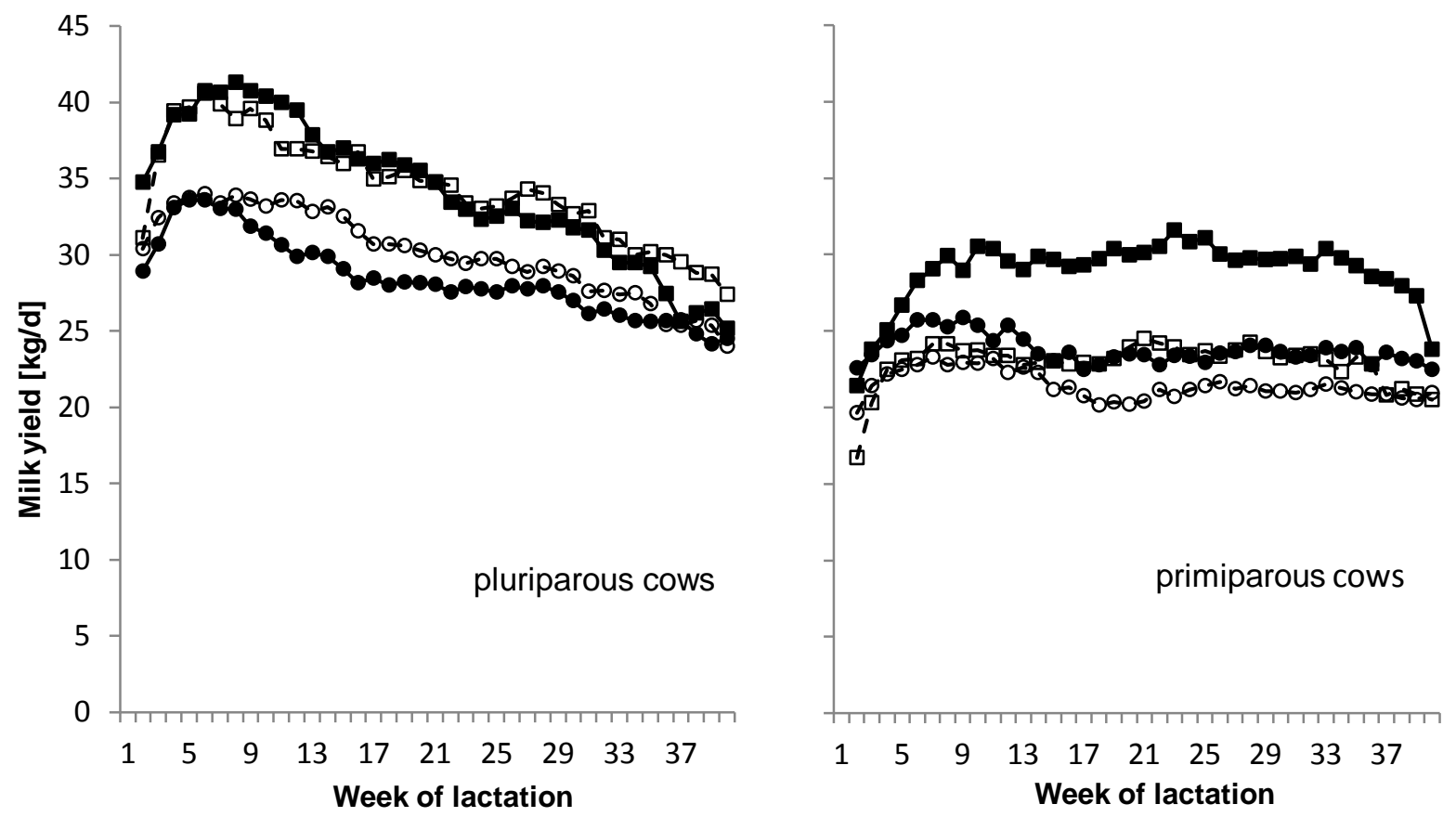

Figure 2 Changes in milk yield (means) in feeding groups over 40-day experimental period:

\footnotetext{
$\longrightarrow 60+\mathrm{NA} ;-\neg-60-; \longrightarrow 30+\mathrm{NA} ;-\multimap-$ - $30-$

$60 \%$ or $30 \%$ concentrate; NA: niacin.
} 
Milk fat percentage decreased at high levels of concentrate $(P<0.001)$. Milk protein percentage and milk protein yield were increased by high levels of concentrate $(P<0.001)$. Milk lactose percentage tended $(P=0.061)$ to be increased with level of concentrate. Milk lactose yield was elevated $(P<0.001)$ by level of concentrate. These four parameters were not influenced by niacin supplementation. The fat-to-protein quotient $(F-P-Q)$ was decreased $(P<0.001)$ by high concentrate levels (60\%), and there was an interaction between concentrate and niacin $(P=0.002)$.

In rumen fluid, the molar proportions of the volatile fatty acids over the four sampling times are shown in Figure 3. The groups kept on 60\% concentrate, namely Groups $60+$ NA and $60-$, revealed lower molar proportions of acetic acid $(P<0.001)$ and higher proportions of propionic acid $(P<0.001)$ and valeric acid $(P<0.001)$. The groups receiving $30 \%$ concentrate revealed a higher molar proportion of acetic acid and lower proportions of propionic and valeric acid. In addition, the molar proportion of propionic acid was influenced by an interaction between concentrate and niacin $(P=0.031)$. The group receiving $60 \%$ concentrate with supplemental niacin had a higher molar proportion of propionic acid in rumen fluid than Group 60-. The only exception was in the first week of lactation. At this time point the molar proportion of propionic acid was higher for Group 60- compared to Group 60+ NA (Figure 3.
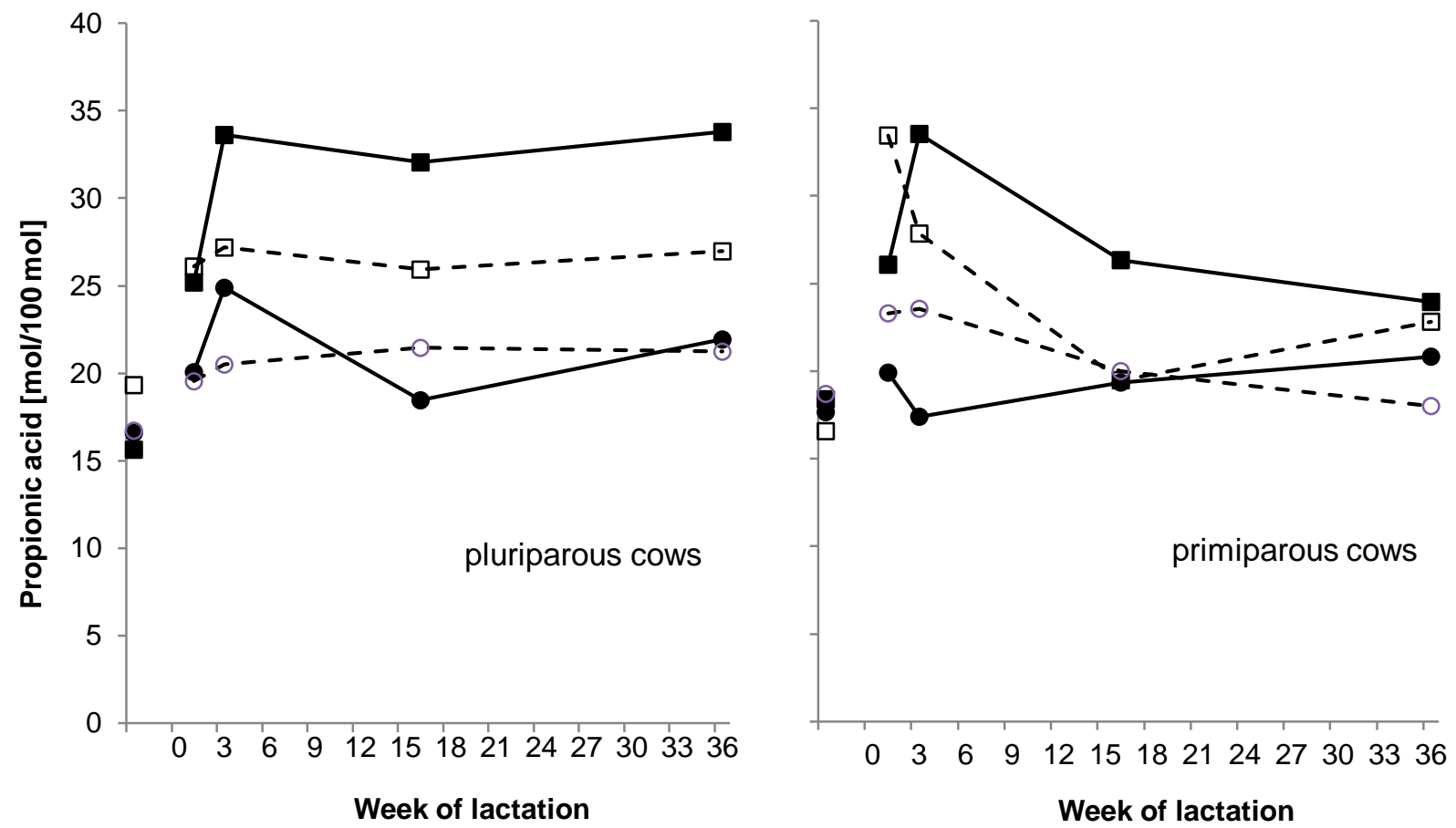

Figure 3 Propionic acid concentration in rumen fluid of the cows in the 1st, 3rd, 16th and 36th weeks of lactation in the various feeding groups:

$\longrightarrow 60+\mathrm{NA} ;-\because-60-; \quad \longrightarrow 30+\mathrm{NA} ;-\multimap-30-$

$60 \%$ or $30 \%$ concentrate; NA: niacin.

Total ruminal SCFA concentration was increased by the level of concentrate $(P=0.001)$, as well as niacin supplementation $(P<0.001)$ (Figure 4). Niacin supplementation decreased $(P=0.014)$ plasma glucose concentration, and there was a tendency for interaction between niacin and concentrate proportion $(P=0.062)$ (Figure 5$)$.

The plasma glucose concentration ranged from $3.4 \mathrm{mmol} / \mathrm{L}$ in Group $60+\mathrm{NA}$ in the $1 \mathrm{st}$ week of lactation to $4.0 \mathrm{mmol} / \mathrm{L}$ in Group 30- in the 16th week of lactation. BHB and NEFA concentrations (Figure 8) were unaffected by niacin supplementation. Only concentrate level influenced plasma BHB concentration $(P<0.001)$. Low concentrate proportion led to higher plasma BHB concentrations and vice versa. 

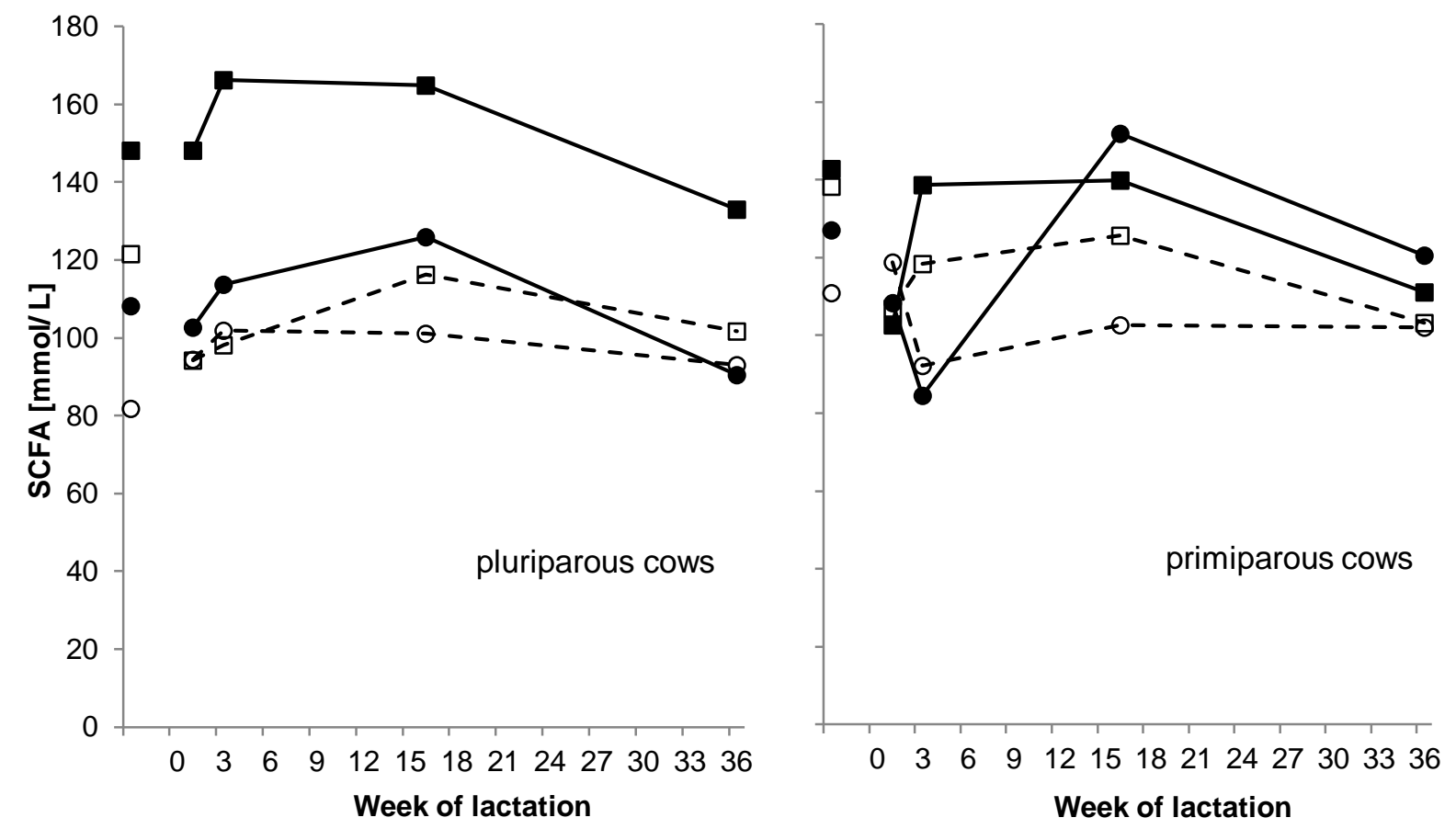

Figure 4 Total short-chain fatty acid (SCFA) concentration in milk of pluriparous cows (left) and primiparous cows (right) in the 1st, 3rd, 16th and 36th week of lactation in the different feeding groups:

$\longrightarrow 60+\mathrm{NA} ;-\square-60-; \longrightarrow 30+\mathrm{NA} ;-\multimap-30-$

$60 \%$ or $30 \%$ concentrate; NA: niacin.
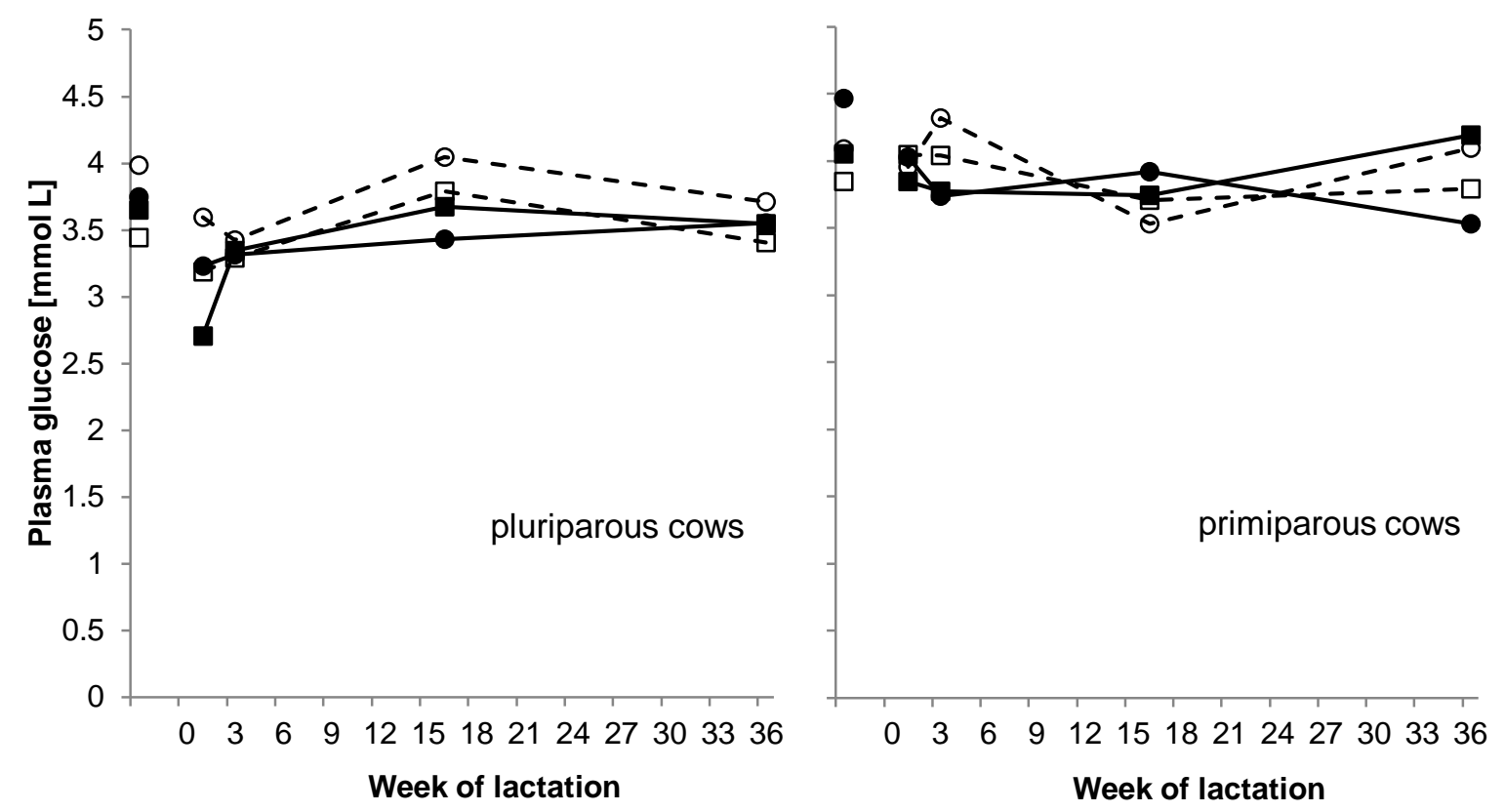

Figure 5 Plasma glucose concentrations of the cows in the 1st, 3rd, 16th and 36th week of lactation: $\longrightarrow 60+N A ;-\square-60-;$ $\longrightarrow 30+N A ;-O-30-$ $60 \%$ or $30 \%$ concentrate; NA: niacin.

Plasma NAM (Figure 6) was generally higher $(P<0.001)$ in cows fed niacin-supplemented diets. However, the elevation in plasma NAM level was even more pronounced when the cows were fed the diet with the low concentrate level (Group $30+N A$ ) and caused significant interactions between concentrate proportion and niacin supplementation $(P<0.001)$. 

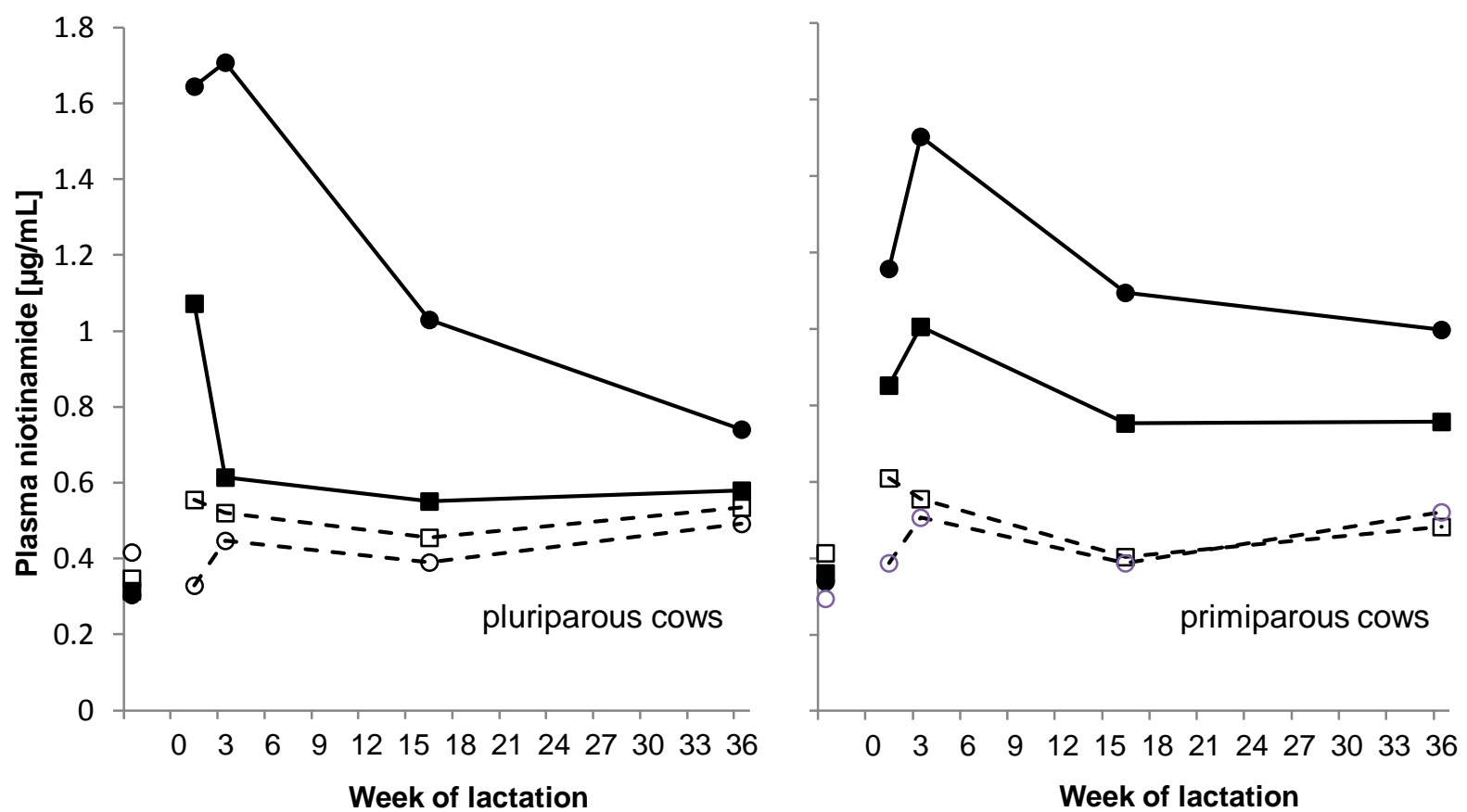

Figure 6 Plasma nicotinamide concentrations of the cows in the 1st, 3rd, 16th and 36th week of lactation in the different feeding groups:

\footnotetext{
$60+N A ;-\neg-60-; \longrightarrow 30+N A ;-\multimap-30-$.

$60 \%$ or $30 \%$ concentrate; NA: niacin.
}

Plasma NAM values were minimal; $0.36 \mu \mathrm{g} / \mathrm{mL}$ in Group $30-$ in the first week of lactation, and maximal $1.62 \mu \mathrm{g} / \mathrm{mL}$ in Group $30+\mathrm{NA}$ in the third week of lactation.

\section{Discussion}

In short-term studies, the effects of dietary supplementation of niacin on performance and metabolic parameters of dairy cows have been well investigated in the transition period, during early lactation, and for a few weeks in mid lactation. However, there is a dearth of studies of the long-term effects on dairy cows of high doses of niacin supplementation with different concentrate proportions. It was found that concentrate level $(18 \%-60 \%)$ with a low level of niacin supplementation (6 - 12 $\mathrm{g} / \mathrm{d} / \mathrm{cow}$ ) in the diet influences the fate of supplemental niacin and the rate of ruminal niacin production or degradation, and therefore the mode of action of niacin supplementation (Niehoff et al., 2009a). Thus, the aim of the present study was to investigate the effects of high doses of niacin supplementation with two concentrate levels over an entire lactation period.

Concentrate levels had a great influence on many of the parameters (Tables 3 and 4). However, many of these effects were found in or caused by the primiparous cows. These effects were responsible for the detected significant interactions.

In agreement with Jaster \& Ward (1990), Martinez et al. (1991) and Erickson et al. (1992), DMI was not affected by supplemental niacin. In Groups $60+\mathrm{NA}$ and 60-, in early lactation (up to the seventh week) DMI increased faster than in Groups $30+$ NA and 30-. In early lactation (up to 4 - 8 weeks), the DMI of Group $60+$ NA increased. Over the course of the trial, and from week 8 of lactation in particular, the cows compensated for the low concentrate level with higher DMI and consequently their energy balance was increased (Figure 7), which was partially caused by a lower performance level.

In the present study, $24 \mathrm{~g}$ niacin supplementation per day per cow did not lead to a significant difference in milk yield. These results are similar to those of studies by DiCostanzo et al. (1997), which investigated the effects of $12 \mathrm{~g}, 24 \mathrm{~g}$ and $36 \mathrm{~g}$ supplemental niacin in cows (90 d of lactation) over three consecutive 17-d periods. This matches numerous investigations performed earlier with lower levels of niacin (Erickson et al., 1990; Martinez et al., 1991 and Christensen et al., 1996). However, when only the primiparous cows that received niacin were considered, increased milk yield could be found in early lactation, which agrees with other studies (Jaster \& Ward, 1990; Young \& Smith, 1994). Moreover, over the entire lactation period, niacin-supplemented primiparous cows showed enhanced milk production compared with unsupplemented primiparous cows. It is suggested that enhanced 

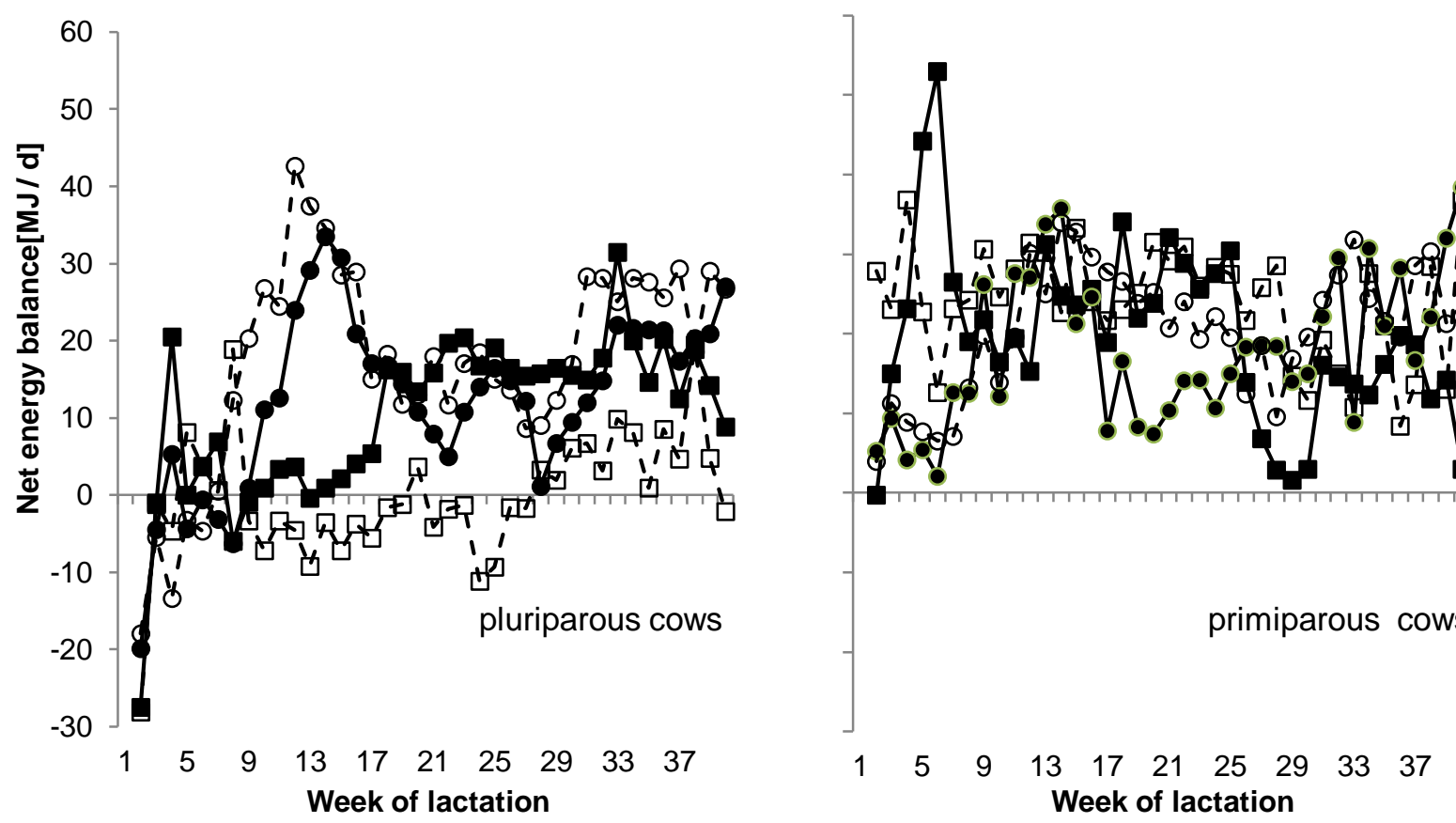

Figure 7 Development of net energy balance (means) of the cows for the four feeding groups:

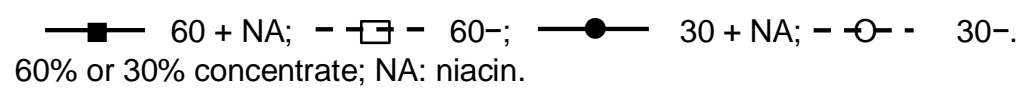

production of microbial protein might explain the increase in milk production when feeding nicotinic acid (Riddell et al., 1981). Holter et al. (1983) suspected that niacin supplementation affected the secretion of milk fat negatively via depressed fat mobilization. These authors assumed that enhanced production of microbial protein might explain increases in milk production. But the primiparous cows in the trial were minimally conditioned at calving (score 2 on a scale of $5=$ fat to $1=$ thin) when feeding NA. However, the data were evaluated for primiparous and pluriparous animals over the entire lactation period. In this period, the metabolic situation varied. In addition, taking cows and heifers together, the animals were in a less pronounced negative energy balance, so no effect was found on milk yield or FCM yield. This is in agreement with Niehoff et al. (2009a), who concluded that the absence of a niacin effect could be explained because the cows were too far into lactation, and thus not in a negative energy balance (Ottou et al., 1995), as in the present trial when cows and heifers were evaluated together. If they were considered separately, it could be seen that the cows had entered a negative balance (Figure 7), owing to their higher milk performance. In contrast, Cervantes et al. (1996) found increased milk yield due to niacin supplementation in mid-lactation when cows were probably not in a negative energy balance. Drackley et al. (1998) evaluated the effect of $12 \mathrm{~g}$ niacin supplementation per day over 40 lactation weeks, and found that milk production and FCM increased. Similarly, Schwab et al. (2005) demonstrated increased milk yield and FCM in a metaanalysis. In agreement with Driver et al. (1990), Jaster \& Ward (1990) and Christensen et al. (1992) who used quantities between $6 \mathrm{~g} / \mathrm{d}$ and $12 \mathrm{~g} / \mathrm{d}$ supplemental niacin, no effect was detected on milk fat content for niacin supplementation. In the present study niacin had no effect on milk fat content. In most studies reviewed by Niehoff et al. (2009a), no effect was found for milk fat yield or milk protein content or yield. Differing from this, Belibasakis \& Tsirgogianni (1996) found increased fat concentration and yield due to niacin $(10 \mathrm{~g} / \mathrm{d})$; Erickson et al. (1992) found milk protein concentration increased (12 g NA/d); while Drackley et al. (1998) found it decreased (12 g/d). Lactose concentration and yield were unaffected, similar to the results of Christensen et al. (1992), Bernard et al. (1995), Ottou et al. (1995) and Minor et al. (1998), in which $6 \mathrm{~g} / \mathrm{d}$ to $12 \mathrm{~g} / \mathrm{d}$ niacin were supplemented. Thus, $24 \mathrm{~g}$ supplemental niacin did not affect milk components, similar to the results of Morey et al. (2011), in which $24 \mathrm{~g} / \mathrm{d} / \mathrm{cow}$ were applied, divided into two daily portions of encapsulated niacin. Reasons for differing results possibly include stage of lactation, quantity of niacin supplementation, feeding regimen, and time segment.

In most earlier studies significant effects could not be detected on blood glucose concentration due to niacin (Martinez et al., 1991; Erickson et al., 1992 and Lanham et al., 1992). Only a few studies recorded increased glucose concentration (Ghorbani et al., 2008; Karkoodi \& Tamizrad, 2009). In contrast, in the present trial the researchers found significantly lower plasma glucose concentrations in 
cows that were receiving supplemental niacin compared with those on the unsupplemented diets. Also Morey et al. (2011) found lower plasma glucose concentrations in niacin-supplemented cows, but only pre-partum and only in pluriparous cows. Morey et al. (2011) found a parity effect pre-partum and a trend postpartum due to $24 \mathrm{~g}$ supplemental encapsulated niacin, while the present study detected a parity effect postpartum. Pluriparous cows developed significant lower plasma glucose concentrations than primiparous cows. It is possible that the lower glucose concentration in niacin-supplemented pluriparous cows was due to a niacin-mediated increased sensitivity to insulin (Pires et al., 2007). Although in comparison with the reference range for glucose $(3.0-3.3 \mathrm{mmol} / \mathrm{L})$ the glucose values in the present study were already high, the niacin-supplemented Groups $60+$ NA and $30+$ NA revealed a slight but significant lower plasma glucose concentration compared with the unsupplemented groups, namely Groups $60-$ and 30-. Glucose concentration in blood is regulated by a large number of factors. After feed intake, the SCFA concentrations in blood increase and most glucose is supplied by gluconeogenesis from propionate acid in the liver. In the present study, Groups $60+$ NA and 60had high propionic acid concentrations in rumen fluid owing to the high concentrate proportion and therefore higher plasma glucose concentration. However, Groups $30+$ NA and 30- revealed high plasma glucose concentrations too. Overall, these high glucose concentrations may be justified by time after feed intake, when samples were drawn. Moreover, the primiparous cows in particular revealed higher glucose values, and therefore the overall result in plasma glucose concentration (Figure 5). Niacin-supplemented heifers developed higher blood glucose concentration mid lactation (week 16), but this was masked by the evaluation of all animals, because the plasma glucose concentration of the cows showed the opposite. It is noticeable that in week 1 of lactation in particular the cows of Group $60+$ NA developed the lowest glucose values, which is reflected in the molar proportion of propionic acid in Figure 3 and the total SCFA concentration of week 1 of lactation in Figure 4.

Furthermore, Oba \& Allen (2003) found that increased secretion of insulin because of enhanced concentration of SCFAs, especially propionate, seemed to be responsible for the decrease in blood glucose levels. That may explain the lower glucose concentrations in Group $60+$ NA. This group had the highest molar proportion of propionic acid, which could have resulted in higher insulin secretion. Hence lower plasma glucose concentrations in Group 60 + NA might be due to an increase in insulin secretion because of a higher propionate supply from the rumen. However, this would not match the results of Group $30+N A$, which revealed slightly lower glucose concentrations, but did not have a higher concentration of propionic acid in the rumen fluid. Another possible explanation is that niacin might increase plasma insulin (Horner et al., 1986) and therefore lower glucose content in Groups 60 + NA and 30 + NA. Pires \& Grummer (2007) achieved enhanced glucose clearance when plasma NEFA concentration was reduced by nicotinic acid, but the animals in their trial were fed restrictively. The animals in the present trial had no reduced NEFA due to nicotinic acid. Therefore, the lower glucose concentrations cannot be explained by increased glucose clearance. However, the direct effects of niacin on plasma glucose, such as stimulating glucose utilization in peripheral tissues and suppressing glucose production by the liver, are not known (Morey et al., 2011).

No effect was observed on plasma NEFA or BHB concentrations owing to niacin supplementation. This is in agreement with studies by Chilliard \& Ottou (1995), Cervantes et al. (1996) and Christensen et al. (1996). There was only decreasing BHB concentration owing to the high concentrate level. Animals were too far into lactation and not under sufficient metabolic stress to show effects. However, if cows and heifers were considered separately in week 1 of lactation, the niacinsupplemented cows and heifers of Group 60 + NA had lower NEFA concentrations than Group 60(Figure 8).

Martinez et al., 1991 detected increases in NEFA concentration, but in their trial fat was also supplemented. Decreases in NEFA were also observed by Pires \& Grummer (2007) and Pires et al. (2007), but in feed-restricted, non-lactating, non-gestating cows.

In addition, different niacin amounts were infused abomasally, which suppressed lipolysis and therefore lowered NEFA concentration. Moreover, in humans NAM is a weak agonist to the receptor (HM74A), which exerts an antilipolytic action after stimulation with NA (Wise et al., 2003). Niehoff et al. (2009a) noted that there is disagreement about the existence of NA in blood. Supplemented niacin is rapidly converted to NAD and then hydrolysed to NAM. It was concluded that NAM is the main transport form of niacin in blood (Henderson, 1983). In addition, Santschi et al. (2005b) estimated that only $5 \%$ of supplemental nicotinic acid is bioavailable. Morey et al. (2011) suggested most supplemented NA is converted to NAM after absorption. In the present study, only NAM could be found in plasma, supporting the assumption that supplemental niacin was converted to NAM, which might be the reason that NEFA did not decrease because of NA, which has a high affinity with the receptor (HM74A). In the present trial, NA was below detection limit. 

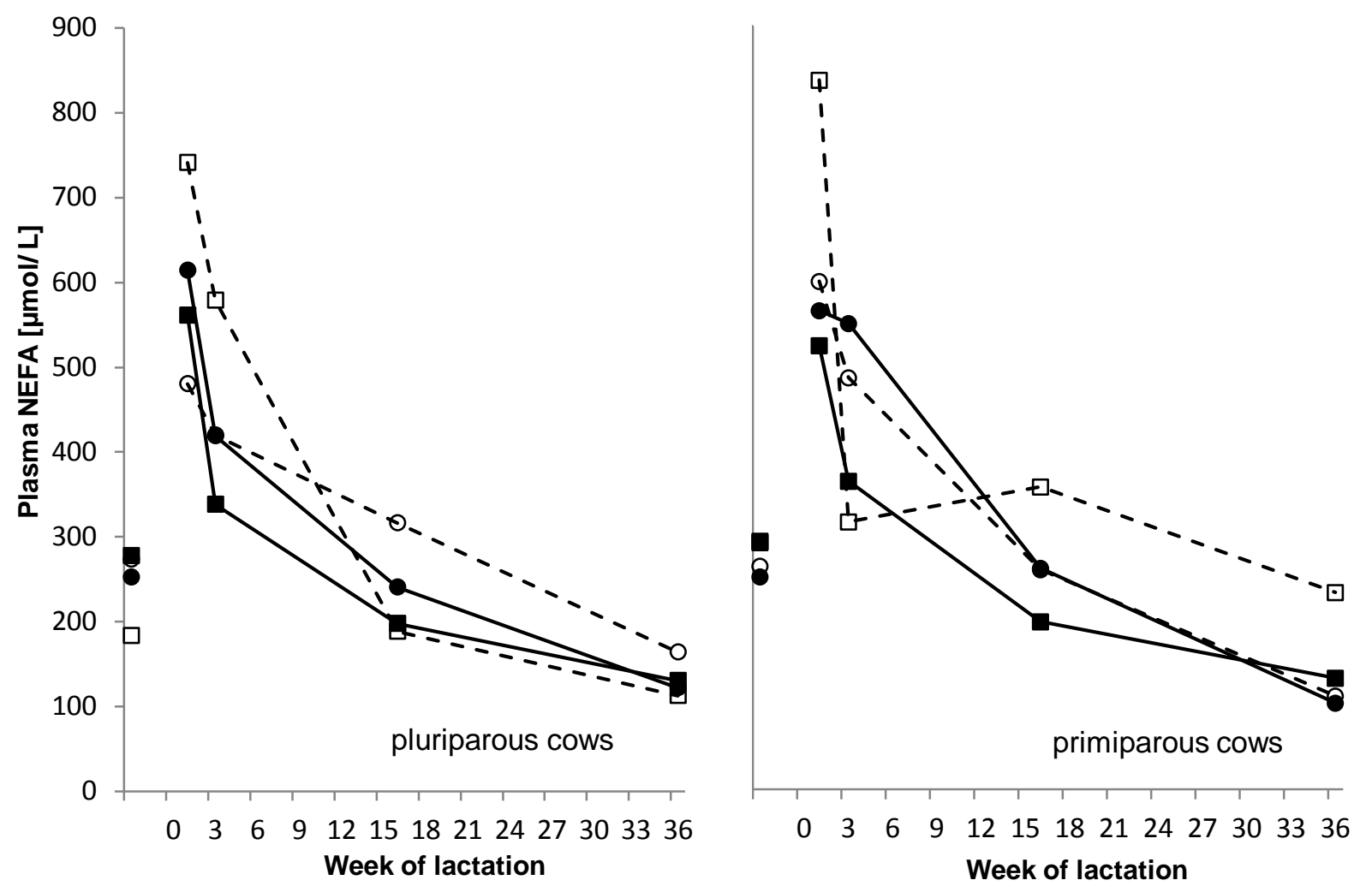

Figure 8: Plasma non-esterified fatty acid (NEFA) concentrations of the cows in the 1st, 3rd, 16th and 36th weeks of lactation in the various treatment groups:

$\longrightarrow 60+N A ;-\square-60-; \longrightarrow 30+N A ;-\multimap-30-$

High blood NAM concentrations are usually the result of a high level of concentrate in the diet combined with niacin (Niehoff et al., 2009b), but in the present study the highest NAM plasma concentration was found in Group 30 + NA. In agreement with Driver et al. (1990), Ottou et al. (1995) and Cervantes et al. (1996), an increase was found in plasma NAM concentration after niacin supplementation. The trial started (third week ante-partum) with basal plasma NAM concentrations of nearly $0.35 \mu \mathrm{g} / \mathrm{mL}$ in all feeding groups.

Increased plasma NAM levels may result from supplemental niacin in the diet or from increased intake of fermentable organic matter, which stimulates production by ruminal microbes (Morey et al., 2011). Furthermore, higher niacin degradation in Group 60 + NA than in Group 30 + NA might have occurred owing to the high level of concentrate, which might negatively influence the ruminal environment, and thus rumen microbes, and accordingly decreases in ruminal production. Niehoff et al. (2013) indicated that degradation in the rumen or absorption before the duodenal cannula may take place. The mechanism that leads to the disappearance of supplemental niacin is not known. Moreover, Niehoff et al. (2013) concluded that synthesis of niacin is lower in rations containing a high proportion of forage, so the high plasma niacin content of Group $30+$ NA in the present study is probably because of the supplemental niacin. There is lack of understanding of the effects of feeding on niacin degradation and synthesis. However, there was an increase in vitamin production when microbial growth was enhanced, and the degradation of supplemental niacin seemed to be reduced simultaneously, but microbial growth was not measured. Mechanisms such as degradation and degradation by microflora that is greater than synthesis are not known (Niehoff et al., 2009a). In addition, niacin synthesis did not seem to occur if NA or NAM was supplemented (Hannah \& Stern, 1985; Niehoff et al., 2013). Santschi et al. (2005a) stated that diets with higher amounts of concentrate affected ruminal vitamin synthesis, and substantial losses occurred. This is perhaps a reason for the lower plasma NAM concentrations in Group $60+$ NA. Degradation by ruminal microflora greater than synthesis was also found by Schwab et al. (2006). Therefore, the lower concentrate proportion may lead to alterations in microbial composition, and therefore greater vitamin synthesis or less degradation could occur. 


\section{Conclusions}

The addition of $24 \mathrm{~g}$ niacin to the various concentrate levels resulted in decreased plasma glucose concentration and increased plasma niacin concentration, but DMI, milk performance, rumen fluid composition and plasma levels of NEFA and BHB remained unaffected. The considerable variation between multiparous and primiparous cows must be taken into account. Primiparous cows responded more sensitively to niacin supplementation. Niacin supplementation over the entire lactation period positively affected the milk yield of primiparous cows, total SCFA concentration, and the molar proportion of propionic acid in rumen fluid of all supplemented cows. However, the high level of concentrate must be considered, since feeding these levels supports the development of acidosis.

Plasma NAM concentration was enhanced by supplemental niacin. Group $30+$ NA showed the highest values. Therefore, further research is necessary to obtain more information about factors that influence niacin synthesis, degradation and absorption. In addition, the decreased plasma glucose content due to niacin supplementation needs further examination.

\section{Acknowledgements}

The assistance of the co-workers of the Institute of Animal Nutrition and the Experimental Station of the Institute of Animal Nutrition, Braunschweig, Germany, in performing the experiment and analyses is gratefully acknowledged.

\section{References}

Belibasakis, N.G. \& Tsirgogianni, D., 1996. Effects of niacin on milk yield, milk composition, and blood components of dairy cows in hot weather. Anim. Feed Sci. Technol. 64, 53-59.

Bernard, J.K., Quigley, J.D., Dowlen, H.H. \& Lamar, K.C., 1995. Supplemental niacin and heat-treated whole soybeans for Jersey cows during early lactation. J. Dairy Sci. 78, 2016-2023.

Breves, G. \& Lebzien, P., 2009. Basic principles of intraruminal carbohydrate, protein and vitamin metabolism in lactating cows. Züchtungskunde 81, 421-428 (in German, English summary).

Cervantes, A., Smith, T.R. \& Young, J.W., 1996. Effects of nicotinamide on milk composition and production in dairy cows fed supplemental fat. J. Dairy Sci. 79, 105-113.

Chilliard, Y. \& Ottou, J.F., 1995. Duodenal infusion of oil in midlactation cows. 7. Interaction with niacin on responses to glucose, insulin, and beta-agonist challenges. J. Dairy Sci. 78, 2452-2463.

Christensen, R.A., Clark, J.H., Drackley, J.K. \& Blum, S.A., 1992. Effects of nicotinamide on energy and fatty acid utilization by lactating dairy cows. California Agriculture Fact Sheet, pp. 22-25.

Christensen, R.A., Overton, T.R., Clark, J.H., Drackley, J.K., Nelson, D.R. \& Blum, S.A., 1996. Effects of dietary fat with or without nicotinic acid on nutrient flow to the duodenum of dairy cows. J. Dairy Sci. 79, 1410-1424.

DLG (Deutsche Landwirtschaftsgesellschaft), 1997. DLG-Futterwerttabellen Wiederkäuer. DLGVerlags $\mathrm{GmbH}$, Frankfurt/Main (in German).

DiCostanzo, A., Spain, J.N. \& Spiers, D.E., 1997. Supplementation of nicotinic acid for lactating Holstein cows under heat stress conditions. J. Dairy Sci. 80, 1200-1206.

Drackley, J.K., LaCount, D.W., Elliott, J.P., Klusmeyer, T.H., Overton, T.R., Clark, J.H. \& Blum, S.A., 1998. Supplemental fat and nicotinic acid for Holstein cows during an entire lactation. J. Dairy Sci. 81, 201-214.

Drackley, J.K., Richard, M.J., Beitz, D.C. \& Young, J.W., 1992. Metabolic changes in dairy-cows with ketonemia in response to feed restriction and dietary 1,3-butanediol. J. Dairy Sci. 75, 1622-1634.

Driver, L.S., Grummer, R.R. \& Schultz, L.H., 1990. Effects of feeding heat-treated soybeans and niacin to high producing cows in early lactation. J. Dairy Sci. 73, 463-469.

Erickson, P.S., Trusk, A.M. \& Murphy, M.R., 1990. Effects of niacin source on epinephrine stimulation of plasma nonesterified fatty acid and glucose concentrations, on diet digestibility and on rumen protozoal numbers in lactating dairy cows. J. Nutr. 120, 1648-1653.

Erickson, P.S., Murphy, M.R. \& Clark, J.H., 1992. Supplementation of dairy-cow diets with calcium salts of long-chain fatty-acids and nicotinic-acid in early lactation. J. Dairy Sci. 75, 1078-1089.

Flachowsky, G., 1993. Niacin in dairy and beef cattle nutrition. Arch. Anim. Nutr. 43, 195-213.

Fronk, T.J., Schultz, L.H. \& Hardie, A.R., 1980. Effect of dry period over-conditioning on subsequent metabolic disorders and performance of dairy-cows. J. Dairy Sci. 63, 1080-1090.

Gaines, W.L., 1928. The energy basis of measuring milk yield in dairy cows. Illinois Agric. Exp. Sta. Bull. 308, 401-438.

Geissler, C., Hoffmann, M. \& Hickel, B., 1976. Gas-chromatographic estimation of volatile fatty acids. Arch. Anim. Nutr. 26, 123-129.

GfE, 2001. Empfehlungen zur Versorgung mit Vitaminen. In: Empfehlungen zur Energie- und Nährstoffversorgung der Milchkühe und Aufzuchtrinder. pp. 105-135. Ausschuß für 
Bedarfsnormen der Gesellschaft für Ernährungsphysiologie, DLG-Verlag, Frankfurt/Main (in German).

Ghorbani, B., Vahdani, N. \& Zerehdaran, S., 2008. Effects of niacin on milk production and blood parameters in early lactation of dairy cows. Pak. J. Biol. Sci. 11, 1582-1587.

Girard, C.L., 1994. Concentrations of folates in ruminal content of steers. Responses to dietary supplement of folic acid in relation with the nature of the diet. J. Anim. Sci. 72,1023-1028.

Girard, C.L., 1998. B-complex vitamins for dairy cows: a new approach. Can. J. Anim. Sci. 78, 71-90.

Girard, C.L. \& Matte, J.J., 2005. Impact of B-vitamin supply on major metabolic pathways of lactating dairy cows. J. Dairy Sci. 88.

Hannah, S.M. \& Stern, M.D., 1985. Effect of supplemental niacin or niacinamide and soybean source on ruminal bacterial fermentation in continuous culture. J. Anim. Sci. 61, 1253-1263.

Hayes, B.W., Mitchell, G.E., Little, C.O. \& Bradley, N.W., 1966. Concentrations of B-vitamins in ruminal fluid of steers fed different levels and physical forms of hay and grain. J. Anim. Sci. 25, 539-542.

Henderson, L.M., 1983. Niacin. Annu. Rev. Nutr. 3, 289-307.

Holter, J.B., Janicki, F.J., Bartlett, C.A., Hayes, B.W. \& Schwab, C.G., 1983. Niacin supplementation in early lactation. J. Dairy Sci. 78 (Suppl. 1) 167 (Abstract).

Horner, J.L., Coppock, C.E., Schelling, G.T., Labore, J.M. \& Nave, D.H., 1986. Influence of niacin and whole cottonseed on intake, milk yield and composition and systemic responses of dairy cows. J. Dairy Sci. 69, 3087-3093.

Jaster, E.H. \& Ward, N.E., 1990. Supplemental nicotinic acid or nicotinamide for lactating dairy cows. J. Dairy Sci. $73,2880-2887$.

Karkoodi, K. \& Tamizrad, K., 2009. Effect of niacin supplementation on performance and blood parameters of Holstein cows. S. Afr. J. Anim. Sci. 39, 349-354.

Lanham, J.K., Coppock, C.E., Brooks, K.N., Wilks, D.L. \& Horner, J.L., 1992. Effects of whole cottonseed or niacin or both on casein synthesis by lactating Holstein cows. J. Dairy Sci. 75, 184-192.

Lohölter, M., Meyer, U., Rauls, C., Rehage, J. \& Dänicke, S., 2013. Effects of niacin supplementation and dietary concentrate proportion on body temperature, ruminal $\mathrm{pH}$ and milk performance of primiparous dairy cows. Arch. Anim. Nutr. 67, 202-218.

Martinez, N., Depeters, E.J. \& Bath, D.L., 1991. Supplemental niacin and fat effects on milkcomposition of lactating Holstein cows. J. Dairy Sci. 74, 202-210.

Minor, D.J., Trower, S.L., Strang, B.D., Shaver, R.D. \& Grummer, R.R., 1998. Effects of nonfiber carbohydrate and niacin on periparturient metabolic status and lactation of dairy cows. J. Dairy Sci. 81, 189-200.

Morey, S.D., Mamedova, L.K., Anderson, D.E., Armendariz, C.K., Titgemeyer, E.C. \& Bradford, B.J., 2011. Effects of encapsulated niacin on metabolism and production of periparturient dairy cows. J. Dairy Sci. 94, 5090-5104.

Niehoff, I.D., Hüther, L. \& Lebzien, P., 2009a. Niacin for dairy cattle: a review. Br. J. Nutr. 101, 5-19.

Niehoff, I.D., Hüther, L., Lebzien, P., Bigalke, W., Dänicke, S. \& Flachowsky, G., 2009b. Investigations on the effect of a niacin supplementation to three diets differing in forage to concentrate ratio on several blood and milk variables of dairy cows. Arch. Anim. Nutr. 63, 203-218.

Niehoff, I.D., Hüther, L., Lebzien, P. \& Flachowsky, G., 2013. The effect of a niacin supplementation to diets differing in forage to concentrate ratio on ruminal fermentation and flow of nutrients to the duodenum of dairy cows. Landbauforsch. Appl. Agric. Forestry Res. 63, 143-154.

Nilson, K.M., Owen, F.G. \& Georgi, C.E., 1967. Effect of abrupt ration change on rumen microorganisms and niacin and vitamin $B_{6}$ content of rumen fluid and milk. J. Dairy Sci. 50, 1172-1176.

NRC, 2001. Vitamins. In: Nutrient Requirements of Dairy Cattle, National Academy Press,. Washington D.C., USA. pp.162-177.

Oba, M. \& Allen, M.S., 2003. Dose-response effects of intraruminal infusion of propionate on feeding behavior of lactating cows in early or midlactation. J. Dairy Sci. 86, 2922-2931.

Ottou, J.F., Doreau, M. \& Chilliard, Y., 1995. Duodenal Infusion of rapeseed oil in midlactation cows. interaction with niacin on dairy performance and nutritional balance. J. Dairy Sci. 78, $1345-1352$.

Pires, J.A.A. \& Grummer, R.R., 2007. The use of nicotinic acid to induce sustained low plasma nonesterified fatty acids in feed-restricted Holstein cows. J. Dairy Sci. 90, 4498-4498.

Pires, J.A.A., Pescara, J.B. \& Grummer, R.R., 2007. Reduction of plasma NEFA concentration by nicotinic acid enhances the response to insulin in feed-restricted holstein cows. J Dairy Sci. 90, 4635-4642.

Riddell, D.O., Bartley, E.E. \& Dayton, A.D., 1981. Effect of nicotinic acid on microbial protein synthesis in vitro and on dairy cattle growth and milk production. J. Dairy Sci. 64, 782-791. 
Santschi, D.E., Berthiaume, R., Matte, J.J., Mustafa, A.F. \& Girard, C.L., 2005a. Fate of supplementary B-vitamins in the gastrointestinal tract of dairy cows. J. Dairy Sci. 88, 2043-2054.

Santschi, D.E., Chiquette, J., Berthiaume, R., Martineau, R., Matte, J.J., Mustafa, A.F. \& Girard, C.L., 2005b. Effects of the forage to concentrate ratio on B-vitamin concentrations in different ruminal fractions of dairy cows. Can. J. Anim. Sci. 85, 389-399.

SAS, 2008. Statistical Analysis Systems User's Guide. SAS Institute Inc., North Caroline, USA.

Schwab, E.C., Caraviello, D.Z. \& Shaver, R.D., 2005. Review: A meta-analysis of lactation responses to supplemental dietary niacin in dairy cows. Prof. Anim. Sci. 21, 239-247.

Schwab, E.C., Schwab, C.G., Shaver, R.D., Girard, C.L., Putnam, D.E. \& Whitehouse, N.L., 2006. Dietary forage and nonfiber carbohydrate contents influence B-vitamin intake, duodenal flow, and apparent ruminal synthesis in lactating dairy cows. J. Dairy Sci. 89, 174-187.

Van Soest, P.J., Robertson, J.B. \& Lewis, B.A., 1991. Methods for dietary fiber, neutral detergent fiber, and nonstarch polysaccharides in relation to animal nutrition. J. Dairy Sci. 74, 3583-3597.

VDLUFA, 2007. Method Book III - The chemical analysis of feedstuffs. VDLUFA-Verlag, Darmstadt, Germany.

Weiss, W.P. \& Ferreira, G., 2006. Water soluble vitamins for dairy cattle. Proceedings of the Tri-State Dairy Nutrition Conference Fort Wayne, IN. pp. 51-63.

Wise, A., Foord, S.M., Fraser, N.J., Barnes, A.A., Elshourbagy, N., Eilert, M., Ignar, D.M., Murdock, P.R., Steplewski, K., Green, A., Brown, A.J., Dowell, S.J., Szekeres, P.G., Hassall, D.G., Marshall, F.H., Wilson, S. \& Pike, N.B., 2003. Molecular identification of high and low affinity receptors for nicotinic acid. J. Biol. Chem. 278, 9869-9874.

Young, J.W. \& Smith, T.R., 1994. Effects of nicotinamide on milk composition and production in dairy cows fed supplemental fat. Antonio Research Fact Sheet. pp. 25-28. 